\title{
Available phosphorus in poultry. 2. Effect of phosphorus in diet on performance of chicks, bone composition and strength, and calcium and inorganic phosphorus in blood plasma $^{1}$
}

\author{
A. R. El Boushy \\ Department of Poultry Husbandry, Agricultural University, P.O. Box 338, \\ $6700 \mathrm{AH}$ Wageningen, the Netherlands
}

Received 25 October 1978; accepted 26 June 1979

Key words: available phosphorus, chick, growth, feed conversion, tibia, ash, breaking strength

\section{Summary}

In each of two trials, medium heavy layers were crossed with White Cornish (Hybro) males to produce 2160 male chicks, which were kept in batteries. Each group was composed of 90 chicks and in four replicates. Three diets contained $0.3,0.5$ and $0.7 \%$ available phosphorus. The low phosphorus basal diet was analysed to contain $0.5 \%$ total phosphorus, of which calculation shows that $0.3 \%$ was available.

1. Body weight of one-day-old chicks did not differ significantly with maternal diet.

2. Body weight, growth and feed consumption of chicks three and seven weeks old were significantly improved with the increasing levels of available phosphorus. 3. Feed conversion did not differ significantly at seven weeks of age, whereas at three weeks of age, there was a significant difference in favour of the $0.7 \%$ level. 4. Calcium and inorganic phosphorus in blood plasma increased significantly with increase in phosphorus level of the diet. There was a clear relation between inorganic phosphorus in plasma and growth until seven weeks of age.

5. Ash, breaking strength and phosphorus of tibia showed a significant increase with the increase in phosphorus level of the diet.

6. There was a relation of ash, breaking strength and in tibia, with phosphorus and inorganic phosphorus in blood plasma.

1 For Part 1, see El Boushy (1979). 


\section{Introduction}

The effect of dietary level of phosphorus on performance, blood and bone characteristics of growing chicks have been investigated by several workers.

Simco \& Stephenson (1961) noticed that with 0.42 to $0.80 \%$ total phosphorus in diet body weight at 8 weeks of age was depressed by a low level of phosphorus. Gardiner (1971) working with diets of 0.47 to $0.89 \%$ total phosphorus and Waldroup et al. (1975) working with diets of 0.13 to $0.63 \%$ available phosphorus concluded that body weight of chicks at 28 days of age was significantly depressed by low levels and improved with high levels.

Formica et al. (1961) reported that when total phosphorus was reduced below $0.6 \%$ growth of broiler chicks to 4 weeks of age, was retarded. A significant increase in growth to 4 weeks of age was obtained with chicks when the total phosphorus content of the diet was increased from 0.59 to $0.72 \%$ (Waldroup et al., 1962) and from 0.47 to $0.89 \%$ (Gardiner, 1971).

Feed intake has been studied by Temperton \& Cassidy (1964) who used diets with $0.41,0.42,0.55,0.60$ and $0.70 \%$ total phosphorus and showed that feed intake at 8 weeks of age was lower at the low levels of phosphorus and highest with $0.6 \%$.

Gardiner (1969) working with diets of $0.44,0.55$ and $0.64 \%$ total phosphorus pointed out that feed/gain ratio was significantly improved with higher phosphorus levels. Mitchell et al. (1972) found that supplementation with $0.12 \%$ available phosphorus of a basal diet with $0.12 \%$ available phosphorus improved the feed/ gain ratio of broiler chicks in the period 4 to 8 weeks of age but higher levels gave no further improvement.

Gardiner (1962, 1969) found that body weight, bone ash, and inorganic phosphorus in plasma increased with each increase in dietary phosphorus.

Simco \& Stephenson (1961) observed that with little total phosphorus $(0.42 \%)$ broilers had less tibial ash than those fed more $(0.80 \%)$. Similar results were reported by Temperton \& Cassidy (1964) and Gardiner (1969), who noted that bone ash increased with each increase in dietary phosphorus. Waldroup et al. (1975) used available phosphorus levels from 0.13 to $0.63 \%$ and observed a similar trend.

\section{Materials and methods}

The hens of medium heavy breed (a cross of three strains developed at the

Department) used in Part 1 (El Boushy, 1979) were crossed with White Cornish (Hybro) males by artificial insemination with pooled semen to produce chicks similar to broilers. Eggs were gathered every 10 days individually from the parents receiving $0.16,0.20,0.40,0.60,0.80$ and $1.00 \%$ available phosphorus and were incubated. The resulting chicks were sexed and finally 1080 male chicks were used for each of two trails (thus in total 2160 chicks). The chicks were kept in batteries with raised wire floors 12 per battery. Feed and water were supplied 
Table 1. Composition of the low phosphorus basal diet for growing chicks.

\begin{tabular}{|c|c|}
\hline Ingredients & $\%(w / w)$ \\
\hline Yellow maize & 50.00 \\
\hline Soya bean oil meal (44\%) & 30.00 \\
\hline Herring meal $(72 \%)$ & 6.50 \\
\hline Lucerne meal (20\%) & 3.00 \\
\hline Animal fat & 5.50 \\
\hline Iodized salt & 0.50 \\
\hline \multirow[t]{2}{*}{ Vitamin and trace elements supplement 1} & 1.00 \\
\hline & 96.50 \\
\hline Variables (Table 2) & 3.50 \\
\hline Total & 100.00 \\
\hline \multicolumn{2}{|l|}{ Calculated analysis } \\
\hline Crude protein & 23.00 \\
\hline Metabolizable energy $(\mathrm{MJ} / \mathrm{kg})$ & 12.86 \\
\hline Fat & 7.60 \\
\hline Crude fibre & 3.70 \\
\hline Calcium & 1.00 \\
\hline Total phosphorus & 0.50 \\
\hline Available phosphorus & 0.30 \\
\hline Methionine & 0.44 \\
\hline Cystine & 0.37 \\
\hline Lysine & 1.34 \\
\hline
\end{tabular}

Table 2. Experimental variables for growing chicks (\%).

\begin{tabular}{|c|c|c|c|}
\hline & 1 & 2 & 3 \\
\hline Available phosphorus & 0.30 & 0.50 & 0.70 \\
\hline Calcium & 1.00 & 1.00 & 1.00 \\
\hline $\mathrm{Ca}: \mathrm{P}$ (available) & 3.33 & 2.00 & 1.43 \\
\hline Basal diet & 96.50 & 96.50 & 96.50 \\
\hline Calcium hydrogen phosphate dihydrate ${ }^{1}(23.3 \%$ Ca, $19 \%$ P) & 0.08 & 1.15 & 2.30 \\
\hline Ground limestone $(35 \% \mathrm{Ca})$ & 1.80 & 1.05 & 0.29 \\
\hline Yellow maize & 1.62 & 1.30 & 0.91 \\
\hline Total & 100.00 & 100.00 & 100.00 \\
\hline
\end{tabular}

1 Trivial name: dicalcium phosphate $\left(\mathrm{CaHPO}_{4} \cdot 2 \mathrm{H}_{2} \mathrm{O}\right)$. 
ad libitum. The house was warmed by blower-heaters thermostatically controlled; artificial light was provided continuously.

The basal diet (Table 1) was formulated to contain $0.5 \%$ total phosphorus as analysed and $0.30 \%$ available phosphorus as calculated. Table 2 shows the variable details of the diet.

The chicks were divided into three dietary treatments with of $0.3,0.5$ or $0.7 \%$ available phosphorus. Each treatment consisted of 4 replicate groups.

Individual body weight and feed consumption were measured weekly in each battery (12 chicks). Mortality was recorded daily. Feed conversion (feed/gain) was calculated weekly.

Blood samples from 30 chicks at random from each replicate were obtained by wing bleeding at 7 weeks of age. Inorganic phosphorus in plasma was estimated by the method of Gardiner (1962) and calcium in plasma by the method of Fales (1953). The same chicks were used for estimation of ash, calcium, phosphorus, and breaking strength of right tibia (Rowland et al. 1967; as given in AOAC, 1970).

All data of the 2160 chicks were analysed factorially for variance and, when applicable, means per treatment were separated by Duncan's multiple range test (1965).

\section{Results and discussion}

Body weight of one-day old chicks was not influenced by the different phosphorus treatment of the maternal diets with $0.16,0.20,0.40,0.60,0.80$ and $1.00 \%$ available phosphorus (Table 3 ).

Body weight and feed consumption at three weeks and seven weeks, and growth to those ages showed significant differences among the three phosphorus levels. The best results were with $0.7 \%$ available phosphorus, but the diet with $0.5 \%$ available phosphorus was almost as good. With $0.3 \%$, values were significantly less. These results are in close agreement with those of Simco \& Stephenson (1961), Formica et al. (1961), Temperton \& Cassidy (1964), Gardiner (1971) and Waldroup et al. $(1962 ; 1975)$.

Feed conversion was significantly better with $0.7 \%$ phosphorus at three weeks of age, but no significant differences were detected at seven weeks of age. These results are similar to those of Gardiner (1969) at four weeks of age and Mitchell et al. (1972) at seven weeks of age.

Blood plasma showed a decrease in calcium from 0.3 to $0.5 \%$ and an increase of phosphorus from 0.3 to $0.7 \%$, both significant. There was a clear relation between inorganic phosphorus in plasma, growth to seven weeks of age and phosphorus in diet. Gardiner (1969) observed a similar relationship.

Phosphorus and ash in bone, and breaking strength of bone increased significantly with each increase in dietary phosphorus. Ash and phosphorus in bone were clearly related to phosphorus in plasma, to growth until seven weeks and to breaking strength. Calcium in bone was unaffected.

When the available phosphorus was increased, phosphorus in blood plasma 
Table 3. The effect of phosphorus on growing chicks performance and other characteristics. ${ }^{1}$

\begin{tabular}{|c|c|c|c|}
\hline \multirow[t]{2}{*}{ Characteristics } & \multicolumn{3}{|c|}{ Available phosphorus (\%) } \\
\hline & 0.30 & 0.50 & 0.70 \\
\hline \multicolumn{4}{|l|}{ Body weight (g) } \\
\hline one day old & 42.30 & 42.40 & 42.05 \\
\hline 3 weeks old & $339.35 a$ & $403.92 \mathrm{~b}$ & $413.15 \mathrm{~b}$ \\
\hline 7 weeks old & $1210.57 \mathrm{a}$ & $1352.87 \mathrm{~b}$ & $1355.77 \mathrm{~b}$ \\
\hline \multicolumn{4}{|l|}{ Growth (g) } \\
\hline 3 weeks - 1 day old & $297.10 \mathrm{a}$ & $361.50 \mathrm{~b}$ & $371.10 \mathrm{~b}$ \\
\hline 7 weeks - 1 day old & $1168.30^{a}$ & $1310.45 b$ & $1313.75^{b}$ \\
\hline \multicolumn{4}{|l|}{ Food consumption (g) } \\
\hline 3 weeks & $543.87 \mathrm{a}$ & $595.47^{b}$ & $596.02^{b}$ \\
\hline 7 weeks & $2455.32 \mathrm{a}$ & $2672.15^{b}$ & $2686.50^{b}$ \\
\hline \multicolumn{4}{|c|}{ Food conversion (food/gain): } \\
\hline 3 weeks & $1.82 \mathrm{a}$ & $1.65^{b}$ & $1.60 \mathrm{~b}$ \\
\hline 7 weeks & 2.10 & 2.05 & 2.05 \\
\hline \multicolumn{4}{|l|}{ Blood plasma analysis ${ }^{2}(\%)$} \\
\hline Calcium & $13.15 \mathfrak{a}$ & $11.80 \mathrm{~b}$ & $12.10^{\mathrm{ab}}$ \\
\hline Phosphorus & $4.85^{\mathrm{a}}$ & $6.80 \mathrm{~b}$ & $7.50 \mathrm{c}$ \\
\hline \multicolumn{4}{|l|}{ Bone analysis ${ }^{2},{ }^{3}$} \\
\hline $\mathrm{Ca} \%$ & 36.95 & 36.95 & 36.90 \\
\hline P \% & $16.70^{a}$ & $17.25 \mathrm{~b}$ & $18.55^{\mathrm{c}}$ \\
\hline Ash \% & $50.85^{a}$ & $53.20 \mathrm{~b}$ & $56.05 \mathrm{c}$ \\
\hline Breaking strength (kgf) ${ }^{4}$ & $6.75 \mathrm{a}$ & $8.55^{b}$ & $9.35^{\mathrm{b}}$ \\
\hline
\end{tabular}

1 Means with different subscripts are significantly different $(P<0.05)$.

${ }^{2}$ Blood plasma analysis and bone analysis were conducted at 7 weeks of age.

3 On a fat-free basis.

$41 \mathrm{kgf} \sim 9.8 \mathrm{~N}$.

increased too, as was reflected in ash and phosphorus in bone and breaking strength. These results agree with those of Simco \& Stephenson (1961), Temperton \& Cassidy (1964), Gardiner (1969) and Waldroup et al. (1975).

\section{Acknowledgment}

I thank Mr A. E. Roodbeen and Mr M. C. Papadopoulos for their skilfull technical assitance and $\mathrm{Mr}$ M. Keuls for guidance in statistical analysis of the data.

\section{References}

Association of Official Analytical Chemists (AOAC), 1970. Methods of analysis, 11th ed. Washington, D.C. 


\section{AVAILABLE PHOSPHORUS IN POULTRY. 2}

Duncan, D. B., 1965. Multiple range and multiple F tests. Biometrics (March) 1-42.

El Boushy, A. R., 1979. Available phosphorus in poultry. 1. Effect of phosphorus levels on the performance of laying hens and their egg quality, hatchability, bone analysis and strength in relation to calcium and phosphorus in blood plasma. Neth. J. agric. Sci. 27: 176-183.

Fales, F. W., 1953. A micromethod for the determination on serum calcium. J. biol. Chem. 204: 577-585.

Formica, S. D., M. J. Smidt, M. M. Bacharach, W. F. Davin \& J. C. Fritz, 1961. Calcium and phosphorus requirements of growing turkeys and chickens. Poult. Sci. 40: 1402.

Gardiner, E. E., 1962. The relationship between dietary phosphorus levels and the level of plasma inorganic phosphorus of chicks. Poult. Sci. 41: 1156-1163.

Gardiner, E. E., 1969. Response of two breeds of chickens to graded levels of dietary phosphorus. Poult. Sci. 48: 986-993.

Gardiner, E. E., 1971. Relationship of energy, phosphorus and breed of chicken to growth and food efficiency. Br. Poult. Sci. 12: 31-39.

Mitchell, R. J., P. W. Waldroup \& K. R. Hazen, 1972. The phosphorus need of broilers from four to eight weeks of age. Poult. Sci. 51: 1839.

Rowland, L. O., Jr., R. H. Harms, H. R. Wilson, I. J. Ross \& J. L. Fry, 1967. Breaking strength of chick bones as an indication of dietary $\mathrm{Ca}$ and $\mathrm{P}$ adequacy. Proc. Soc. exp. Biol. Med. Vol. 126.

Simco, T. F. \& E. L. Stephenson, 1961. Re-evaluation of the calcium-phosphorus requirements of the chick. Poult. Sci. 40: 1188-1192.

Temperton, H. \& J. Cassidy, 1964. Phosphorus requirements of poultry. II. The utilization of phytin phosphorus by the chick for growth and bone formation. Br. Poult. Sci. 5: 81-86.

Waldroup, P. W., C. B. Ammerman \& R. H. Harms, 1962. Comparison of the requirements of battery and floor grown chicks for calcium and phosphorus. Poult. Sci. 41: 1433-1436.

Waldroup, P. W., R. J. Mitchell \& Z. B. Johnson, 1975. The phosphorus needs of young broiler chicks in relationship to dietary nutrient density levels. Poult. Sci. 54: 436-441. 